\section{Sex Difference in the Number of Adipose Cells from Genetically Obese Rats}

IT is well known that there is no increase in the number of adipose cells in many kinds of experimental obesity. In genetically obese mice, obob obese hyperglycaemic ${ }^{1,2}$ or yellow obese $^{3}$ syndromes as well as in hypothalamic obesities produced by aurothioglucose in mice ${ }^{4}$ or stereotaxic lesions in rats ${ }^{5}$, there is only an enlargement of the adipose cells. The same results are obtained in rats made obese by a high fat $\operatorname{diet}^{6}$. There is only one known exception to this rule: obesity induced by a high fat diet in female mice ${ }^{7}$, in which the number of cells is increased by a factor of 2.5. Because male animals were used in all experiments except the last, the question arises whether there may be a sex difference in the adipose tissue development in obese animals.

Genetically obese rats (fafa) ${ }^{8} 2.5$ months old and their litter mates, fed with my control diet, were used. Whole perigenital fat pads were weighed and treated as previously described $^{6}$ : portions of histological sections on slides, projected on the ground glass of a Projectina microscope, were counted for their adipose cells at a magnification of $\times 130$. The mean volume was calculated and the number of adipose cells estimated by the ratio of fat pad weight to mean adipose cell volume $\times 0.91(0.91$ is the measured density of the pads).

Table 1 shows that the body weights of obese rats doubled in the females but increased less in the males. The weight of perigenital fat pads increased 3.2 and 9.7-fold in males and females respectively. Adipose cells enlarged 4.6 and 4.0fold in obese males and females respectively. In male obese rats there were significantly fewer epididymal adipose cells than in their litter mates, but a 2.3 -fold increase in their number was observed in the parametrial cells of the obese females.

Table 1 Weights of the Body and of the Two Perigenital Fat Pads of 2.5 Month Old Genetically Obese Male and Female Rats and Their Litter Mates

\begin{tabular}{lcc}
\hline & $\begin{array}{c}\text { Lean } \\
\text { litter mates }\end{array}$ & Obese \\
& & \\
Males & $276 \pm 16.0$ & $366 \pm 17.3$ \\
Body weight $(\mathrm{g})$ & $9.00 \pm 0.327$ \\
Epididymal fat pad weight $(\mathrm{g})$ & $2.82 \pm 0.260$ & $1,275 \pm 85.2$ \\
Adipose cell volume $\left(\times 10^{3}{\mu \mathrm{m}^{3}}^{3}\right)$ & $276 \pm 25.5$ & $6.50 \pm 0.256$ \\
No. of adipose cells (millions) & $9.34 \pm 0.458$ & \\
Females & & $320 \pm 13.6$ \\
Body weight (g) & $165 \pm 2.4$ & $15.9 \pm 0.71$ \\
Parametrial fat pad weight $(\mathrm{g})$ & $1.64 \pm 0.189$ & $9.48 \pm 0.460$ \\
Adipose cell volume $\left(\times 10^{3} \mu \mathrm{m}^{3}\right)$ & $379 \pm 46.6$ & \\
No. of adipose cells (millions) & $4.08 \pm 0.292$ & \\
& &
\end{tabular}

The cell volume of the obese groups increased, but cell number increased only in the female group (2.3 times). All differences are highly significant $(P<0.01)$. Values are mean \pm s.e. There were six animals in each of the four groups.

Hypertrophy of the adipose cells in the obese females could only account for a parametrial fat pad weight of $1.64 \times 4.0=$ $6.64 \mathrm{~g}-9.26 \mathrm{~g}$ less than the actual weight. And so about $70 \%$ of the weight of the pads was due to formation of new fat cells which were themselves hypertrophied.

These results clearly established a sex difference in the development of perigenital adipose tissue. They are in good agreement with the literature which records no increase in fat cell number in male obese rats or mice ${ }^{1-6}$. But there was a marked hyperplasia in the parametrial adipose cells in the females which was very similar to those observed in female mice made obese by a high fat $\operatorname{diet}^{7}$.
Exceptions to the rule that only hypertrophy is observed in male adult animals had been claimed: there is hyperplasia of adipose cells in rats after repeated injections of insulin ${ }^{8-10}$ or meal feeds ${ }^{11}$. In these animals there was no increase in the weight of the epididymal fat pad, and adipose cell volume seemed to be reduced; the differences, however, were very small. The principal effect, in the two cases, was a great increase in the total DNA content of the pads $(+50 \%$ for meal fed rats $^{11}$ and $+100 \%$ for rats treated with insulin ${ }^{10}$ ). Such differences cannot be the effect of a marked hyperplasia: the weight of fat pads was unchanged and cell volume very slightly smaller; so it can be concluded that there was an increased DNA content in stromal structures. Such an effect has been established in hypophysectomized rats after injections of somatotrophic hormone: the rate of DNA synthesis of supporting and vascular structures was enhanced, but there was no effect on division in adipose cells ${ }^{12}$. In my rats, the histological appearance of perigenital adipose tissue was the same as that described for rats made obese by a high fat diet $^{6}$. There was no difference, except for the size of the cells, between fat tissues of control and obese rats, although there was a marked and similar hyperinsulinism in males as in females in the obese group (to be published later).

I thank A. Alexia for technical assistance.

Laboratory of Biology and Human Nutrition,

DANIEL LEMONNIER

CNAM 292 Rue Saint Martin,

75 Paris 3

Received December 15, 1970.

${ }^{1}$ Hellman, B., Täljedal, I-B., and Westman, S., Acta Morphol. Neerl-Scand., 5, 182 (1962).

${ }^{2}$ Lemonnier, D., Winand, J., Furnelle, J., and Christophe, J. (in the press)

${ }^{3}$ Hellman, B., Thelander, L., and Täljedal, I-B., Acta Anat., $55,286(1963)$.

${ }^{4}$ Hellman, B., Täljedal, I-B., and Petersson, B., Med. Exp., 6, 402 (1962).

${ }^{5}$ Hirsch, J., and Han, P. W., J. Lipid Res., 10, 77 (1969).

6 Lemonnier, D., Arch. Anat. Microsc. Morphol. Exp., 59, 1 (1970).

7 Lemonnier, D., Experientia, 26, 974 (1970).

8 Zucker, L. M., and Zucker, T. F., J. Hered., 52, 275 (1961).

${ }^{9}$ Hausberger, F. X., and Hausberger, B. C., Anat. Rec., 127, 305 (1957).

10 Kazdova, L., and Vrana, A., Horm. Metab. Res., 2, 117 (1970).

11 Braun, T., Kazdova, L., Fabry, P., Lojda, Z., and Hromadkova, V., Metabolism, 17, 825 (1968).

12 Hollenberg, C. H., and Vost, A., J. Clin. Invest., 47, 2485 (1968).

\section{Polychlorinated Biphenyl absorbed from Sediments by Fiddler Crabs and Pink Shrimp}

PolyChloRinated biphenyls (PCBs) are manufactured in the United States, Europe, and Japan and used as plasticizers, flame retardants, insulating and heat exchange fluids and in many other products ${ }^{1}$. Structurally related to DDT, soluble in lipid but relatively insoluble in water, and extremely persistent in the environment ${ }^{2}$, they have been reported in many marine and estuarine organisms ${ }^{3}$. One PCB, 'Aroclor 1254' (Monsanto), was reported in water, sediments, and biota from Escambia Bay, Florida ${ }^{4}$.

In August 1969, pink, white and brown shrimps (Penaeus duorarum, $\boldsymbol{P}$. setiferus, and $\boldsymbol{P}$. aztecus) from Escambia Bay were found to contain whole body residues of 'Aroclor 1254' at concentrations as high as 14.0 p.p.m. Most was concentrated in the hepatopancreas; residues in seven composite samples of at least five shrimps ranged from 0.6 to 120.0 p.p.m. In April 1970, fiddler crabs (Uca minax) collected at three stations along the lower Escambia River and upper Escambia Bay had individual whole body residues of 0.45 to 1.5 p.p.m. 